\title{
Marching forward to the past? : Challenges and prospects for the new theology of land in Zimbabwe
}

By

\author{
${ }^{1}$ Richard S. Maposa, ${ }^{2}$ James Hlongwana and ${ }^{2}$ Tasara Muguti
}

\begin{abstract}
The article seeks to delineate and evaluate some constraints that the new black farmers in the former white commercial farms face in the backdrop of the contested land reform programme in Zimbabwe. Whereas there was euphoria in the manner the peasants 'occupied' the commercial farms, but the current reality on the ground is pessimistic. The study claims that instead of improving the quality of lives, the new black farmers appear to be literally 'marching forward to the past' in light of the continued challenges. This is how a theology of liberation comes to the fore. Methodologically, the descriptive method used a population sampling of fifty resettled farmers who occupied Congela farm in Kwekwe district. This method was corroborated by the participant observations, questionnaires and interviews as techniques to gather data from the field. This triangulation was necessary to facilitate a holistic picture of resource constraints faced by the resettled black farmers. The study concludes by suggesting some recommendations which might help to promote sustainable development, justice and equality in Zimbabwe.
\end{abstract}

Key Words: Black Farmers, Colonialism, Land Reform, Theology of Land

\section{Introduction}

The contemporary land reform programme in Zimbabwe which took off in February 2000 continues to attract attention in several quarters internationally. Some studies on the land reform have been undertaken and have largely focused on the general social, economic and political impact on the Zimbabwean society. However, not much research has been established to delineate the particularistic challenges and implications that the resettled black farmers are experiencing. The present research therefore constitutes one of the studies meant to fill in the gap. First and foremost, it must be noted that any successful farming depends among other things on the availability of human and non-human resources. These include labour, capital, markets, fertilisers, seeds, chemicals and supervision (Oldeive, 2002:40). Zimbabwe's past record as the bread basket of Southern

${ }^{1}$ Lecturer in Liberation Theology and Church History in the Department of Philosophy and Religious Studies, Great Zimbabwe University

${ }^{2}$ Lecturer in History of Ideas in the Department of History and Development studies, great Zimbabwe University 
Africa was inextricably linked to the availability of resources, banks availed funds to the commercial farmers, farm products found their way into the regional and domestic markets, and labour was not a problem, thanks to the availability of migrant labourers from Malawi, Zambia and Mozambique (Tshuma, 2003:46). Road and rail transport ensured that products and inputs were timeously distributed. Apart from availing inputs and funds, some strategic industries were set up to help or support the farming sector. A good example of such an industry is Sable chemicals which manufactured fertilisers. Furthermore, the government established agricultural colleges such as Gwebi, Chibero, Mlezu and Domboshava. These colleges churned out graduates who disseminated technical know-how to the farmers.

The ZANU (PF) party embarked on the resettlement scheme apparently to address the colonial land imbalance. Historically, within the limelight of political discourses, it must be noted that the fast-track land resettlement programme was undertaken to address and redress the colonial imbalances on land allocation. Under colonial rule, black Africans were dispossessed of their land mainly through the obnoxious Land Apportionment Act of 1930 and the Land Husbandry Act of 1951 which condemned blacks to squat in reserves known as the Tribal Trust Land (TTLs). The enactment of these legislative Acts was a serious travesty of justice. For example, whites settlers who numbered not more than 30000 got $49 \%$ of the country's fertile land while black peasants who numbered about 1000 000 got $28.9 \%$ of the land, which was poor in terms of quality. The rest was made conservatories and State land for future development. African blacks got overcrowded and sunk into 'sponsored poverty'. Disgruntlements over the land inequalities contributed much to the rise of Black Nationalism in Southern Rhodesia and the liberation war was mainly fought to restore justice in the area of land ownership in Zimbabwe (Tshuma, 2003:48). In fact, it must be noted that the glaring inequality in the ownership of land between blacks and whites was part of the 'land question' which has continued to dog Zimbabwe to this day.

At independence in 1980 the government launched the first phase of the mass resettlement programme. Millions of peasant families were resettled across the country despite that it was not very successful given the fact that the government lacked funds and other resources needed. The British government did not honour its pledge to finance the resettlement process. Worse, the resettlement programme was underpinned by one of the Lancaster House Constitutional clauses which was based on 'the willing seller, willing buyer' principle (Mutwira et al, 2001:64). Most of the white farmers were not prepared to part with their farms (Tshuma 2003:51). Therefore, landlessness continued to haunt millions of poor black Zimbabweans who eventually invaded white commercial farms as from 2000. The study constitutes a critical case-study that identifies and evaluates some constraints that the re-settled black farmers face in the former white commercial 
farms in Zimbabwe. Specifically, the case-study is drawn from the experiences of the new black farmers situated at Congela resettlement scheme in the Kwekwe district in the Midlands province. The black farmers in Congela fared well in terms of land allocation under the government's resettlement programme which began in February 2000. There was euphoria when the community peasants invaded the fertile farms under the auspices of the fast-track land reform programme.

Looking in retrospect, the mechanics of land reform simply meant whites were evicted from their farms by black peasants through jambanja (excessive violence) so that overnight, blacks became new farmers in the former white commercial farms. The black peasants from the rural communities became 'landlords' and they inherited everything: land, farm implements and farm tenants. In a matter of months, whites were replaced through forceful eviction orders, torture, maims, arrests and other white commercial farmers forced to become émigrés in the neighbouring countries like Zambia, Mozambique, South Africa. Some evicted white farmers even fled to as far countries as Ghana and Nigeria in West Africa to start life anew. In all these developments, the new black occupiers were strongly backed by the war veterans and youthful militias. These invaders were supported by the ZANU PF politicians and government. The government applauded the land seizures because it was meant to redress the historical colonial imbalances. The resettlement programme was rekindled with vigour and therefore was code named, Third Chimurenga (war of liberation). It was argued that infrastructure would be provided later. This is how the land reform programme flawed because there was little planning from the top. It was Max-Neef (1991:38) who claimed that 'Development geared to the satisfaction of fundamental human needs cannot, by definition, be structured from the top downwards. It cannot be imposed either by law or decree. It can only emanate directly from the actions expectations and creative and critical awareness of the protagonists themselves'. This insight is instructive to the present study. The land reform was calculated as a programme to reduce poverty but the parody at hand is that it has turned out to be unrelated to the mitigation of poverty (Magaloni, 2005:8). Despite the land reform exercise, twelve years down the line, the new black 'landlords' continue to experience the spiral of poverty. This is the fountain for the emergence of liberation theology in Zimbabwe. Thus, the study is therefore timeous in exploring the challenges that the black Zimbabweans face as new land owners. It is prudent, however, that we highlight some biblical perspectives of land because of their intricate relatedness to the Zimbabwean scenario. 


\section{Framework of the Study: Perspectives of Land in the Bible}

Theology of land for Christians is anchored in the Bible and drawn especially in the Old Testament. The perspectives run back to the history of the chosen people and their relationship with God, Yahweh. Theologically, land is perceived to belong to God, who is the creator of the universe (Leviticus 25:23). In the conceptions of the Deuteronomist writers, land is linked to human salvation and identity. No land, no people, no identity. In the Old Testament, the faith and redemption of the chosen people are inconceivable without the reality of land. First and foremost, when God promised Abraham that he would be Father of the holy people, land was a key package of the covenant (Genesis 12:7). Even years later when the same God liberated the chosen people from Egyptian bondage, land was promised. Through Jacob, and as freed slaves, these chosen people were given a new name, Israel (Genesis 35:10-12), to express their common identity and heritage. The land was Canaan that was a geographical space and purportedly full of milk and honey (Exodus 3:8, 17). As such, the Israelites were to share joy and freedom together on their newfound land. The durable seal for all the promises to the Israelites was a covenant that God bequeathed to them on Mt Sinai (Exodus 20:1-20).

Nevertheless, it must be noted that when common joy and freedom are denied, land can become a source of dehumanisation, exploitation and oppression. In the Old Testament, for example, we have a classic story of Naboth and his vineyard (1 Kings 21:1ff). Basing on a patrimonial law, Naboth refused to depose away the piece of land of his forebears. King Ahab had intended to grab this piece of land not because of shortage of land but due to human greed, corruption and discrimination. Thus, Naboth went on to lose, both his ancestral piece of rich and fertile land and his precious life. This incident was only an archetype to what befell Israel. Time after time, Israel saw the land of God's promise become the land of durable human problems. The very land that contained 'milk and honey' made great and greedy kings to become 'Machiavellian princes' of death. The good covenant that gave every person a direct access and responsibility to land was usurped by the ruling oligarchy. Time after time, Nathan, Elijah, Amos, Hosea, Isaiah and Jeremiah, one after another, supplied critical voices on behalf of the voiceless, admonishing the cruel kings and their aristocrats of reckless land graft and monopoly of the day. The few privileged people monopolised fertile land. This monopoly is a mark of unequal and unfair distribution of God's gift of land. Each time when there was this injustice, we see that these fearless prophets of Yahweh preached reform in order to re-instate justice in society. That is why these prophets were justifiably depicted as the great champions of social justice for their theology was rooted on the Mosaic traditions of ethical righteousness that must prevail. 
In the contemporary period, the Jews who belong to Zionism, as a political ideology, are claiming the land of Palestine, which is modern Israel, by using historical and biblical perspectives. This land of Israel seemed doomed from time to time, to be cast in the role of a frontier caught between rivals as if it really were at the centre of the world (Halevi, 1987:1). For that reason Zionism has seen a large immigration (relocation) of Jews into Israel and with the systematic emigration (displacement) of Palestinian Arabs from their space, land. Again, as historian Halevi (1987:165) expressed, '...the Jews are a nation. A nation cannot exist without a common territory, but the Jews have no territory, so they need one, without which a nation cannot exist.' In the backdrop of this, modern Israel was born amid blood and fire in 1948. Thereafter, one-third of the population took over exclusive control of two-thirds of the land by driving out, denying and dispersing Arab Palestinians, who are purportedly the indigenous peoples of the land. This unfair land distribution, in the context of modern Israel in the Middle East, forms the heart of the contemporary Palestinian question. As will be described in the next section, the Palestinian scenario has some parallels to the contemporary Zimbabwean situation as well.

The classic stories of Israel, ancient and modern, and her interaction with God are evidently enlightening and didactic in the context of the delicate land reform in Zimbabwe. By taking cue from their biblical and theological standpoint, the Christian churches in Zimbabwe are ensnared to evoke their historical mandate. That mandate calls for the Christian churches to stick to their vocation as a prophetic voice of the voiceless in society. From what we have highlighted, it is critically clear that the issue of land reform in Zimbabwe is deeply radiated in the ancient biblical setting. To some extent, what has happened in Zimbabwe is nothing new but an on-going process in a new horizon. For example, we can cite Reverend Al Simpson, a United Methodist pastor in Chicago and a member of Louis Farrakhan's Nation of Islam delegation that met Zimbabwe's president Robert Mugabe on 13 July 2002 in Harare, who encouraged him to read the Holy Scriptures, particularly Joshua 1:1-18, in the light of the land reform. This passage is a commandment to possess land, be strong and of good courage in fast-tracking the land redistribution. Such external encouragement received publicity in the state-owned media, as theological justification of the land reform became a basic part of the ruling ZANU (PF)'s strategy to win internal support. Drawing from such biblical perspectives and sensibilities the implication is that the Christian churches in Zimbabwe must participate in the land reform programme by adopting new theological voices and pastoral choices that are in line with liberationist discourses in the light of the deepening woes. For this matter, the Christian churches need not negate central government efforts in the current dispensation concerning land reform. As a delicate human commodity, the issue of land has to be addressed honestly and fairly by all stakeholders. Indeed the 
Christian churches constitute a bloc, one such major player, in the gigantic land reform exercise, which is a foundation for any meaningful national development in Zimbabwe. The biblical-land theology is central and very relevant to the current social ecological, economic and political issues in Zimbabwe. Thus, the subject of the land question in Zimbabwe carries some Christian corroboration.

\section{Methodological Issues}

The study was based on the phenomenological approach in which indepth interviews were conducted as part of the fieldwork. The target group was mainly on the black farmers resettled in Kwekwe district which constituted the case-study. Nevertheless, for ethical and confidential reasons, the names of the informants were withdrawn. The study also benefited from electronic media, journals and published books dedicated on Zimbabwe's land reform programme. This study blends the insights of history and theology in its reflection.

\section{Findings of the Study: Constraints and Implications}

The study examines five major constraints that the black farmers face in Congela resettlement area in Kwekwe distract. These are lack of the marketing base, insufficient transport, shortage of labour, shortage of inputs and insufficient agronomists.

\subsection{Erratic Marketing base}

The market base and marketing costs are critical factors which determine whether it is economic to grow a crop in a certain area. If markets are inaccessible, it may not be possible to grow certain crops even though climate and other physical conditions are ideal (Goh Cheng, 2000:104). The resettled black farmers in Congela face marketing challenges which hamper progress in farming. Prior to the land reform in Zimbabwe, the government encouraged productivity and efficiency of farming to small holder farmers by a system of guaranteed prices and input subsidies. The smallholder farmers were also encouraged to diversify production by engaging in both food crop and high value horticulture (Chisvo, 2000). However, the impediment for the black farmers is lack of access to markets. Most farmers in Congela are short-changed by the Grain Marketing Board (GMB). The GMB frustrates farmers by failing to make timeous payments of money. For example, in 2010 famers who delivered grain around May and June had not been paid by September of that year (Nyaungwe, 2010). Since farming is the major source of livelihood for the black farmers it therefore became extremely difficult for most of them to fulfil their financial obligations. Non-lucrative prices that were gazetted by the government were also a thorny issue to the new 
black farmers. As shown in Table below GMB does not offer lucrative prices for the delivered grain.

Table2: Producer Price for Maize

\begin{tabular}{|l|l|}
\hline Year & Price per tonne( US dollar) \\
\hline 2009 & $\$ 245,00$ \\
\hline 2010 & $\$ 265,00$ \\
\hline 2011 & $\$ 285,00$ \\
\hline
\end{tabular}

Source: GMB Statistics, Kwekwe, 2011

The prices are low so much that farmers see no reason in taking part in farming. The price of grain has not appreciated steadily because it is controlled by the government. Black farmers were further frustrated by GMB's requirement that grain which must be delivered should have $12 \%$ or less of moisture content. Nevertheless, most black farmers do not have scientific means to ascertain the expected moisture content. On numerous occasions, the GMB declined to accept grain which was deemed undesirable on account of high moisture content level. The unfortunate farmers withheld their grain. It continues to be tricky for the black farmers to trade in rural areas since rural markets prove to be thin and trading in distant urban markets is not remunerative owing to high transportation and transaction costs.

Access to markets for smallholder farmers can only be improved by establishing close linkages between the farmers, processors, traders and retailers so as to coordinate supply and demand. These linkages may be established through setting up institutions like co-operatives and producers' associations. Furthermore, he argued that co-operatives enable smallholder farmers to sell produce in bulk and to dispose their produce at the most favourable time, guarding them against unscrupulous middlemen. A good example of an institutional marketing cooperative is the Agricultural Trade and Marketing project set up between 2000 and 2010 (Chisvo, 2000). The project was designed to improve smallholder farmers' access to markets and also training them to establish market linkages with the export market particularly for horticulture produce. This then forces the farmers to sell their produce to middlemen who take advantage of the farmers' marketing predicament by offering low prices. The middlemen bring their own packaging materials and transport and offer the farmers lower prices than that offered by the GMB. In spite of these problems, some farmers continue to supply grain to the GMB which enables them to access farm inputs.

Another marketing challenge faced by farmers at Congela is that of a poorly developed information system to link farmers and buyers. Rural farmers by the nature of their geographical location, largely remote and inaccessible, low literacy levels and dispersion are often left out in terms of information. Without relevant 
information it is difficult to make sound business decisions. Most farmers do not know where to sell, prevailing prices or who is buying. Black farmers usually sell to whoever comes to their door step offering low prices. Those middlemen take the produce away to sell at wealth-creating prices. If farmers had the information about the prices and market opportunities, such abuse could be avoided. In fact, the Zimbabwean government should take a leaf from the Ghanaian experience where a telephone company developed mobile phone linked software for farmers, offering a range of functions: price alert, weather forecast, input sources and prices, bids and market places. A similar programme would be helpful to the new farmers in Zimbabwe.

\subsection{Inefficient Transport System}

According to Mnkandla (2001:87) the transport policy in Zimbabwe seeks to service communal areas as well as commercial areas to enable easy delivery of farm produce to the market. However, the Zimbabwean scenario is that, most commercial farming areas are better serviced in terms of road and rail transport than small scale farming areas or communal areas. This was inherited from the colonial era that deliberately discriminated the blacks in favoured of the whites. The argument then was that transport routes are expensive to build and the only way to justify the high costs was their continued use (Munowenyu et al, 2005:249). In white perspective, small-scale farmers were not in dire need of transport networks since they rarely delivered produce to the market. The situation was partially redressed at independence through the construction of roads to serve communal lands. However, small-scale farming areas continue to rely more on road transport than rail. Most of the roads in the communal areas are in a bad state, they are narrow and potholed.

The infrastructure inherited from the former white commercial farmers is dilapidated. The farm feeder roads are impassable due to lack of maintenance. The roads which were previously maintained by commercial farmers have deteriorated after selling land to the government for resettlement in the 1980s. Black farmers at Congela use either ox-drawn or donkey-pulled scorch carts to ferry their produce to the market. As far as transport service is concerned, the area is inaccessible since the once popular Kwekwe-Mvuma road has long been out of use because of the destruction of bridges by Cyclone Elene in 2000. The lack of maintenance has made the road impassable forcing people to access Mvuma from Kwekwe via Gweru, a fairly circuitous route. Transport problem at Congela is also compounded by the fact that the plots are dispersed and there are no feeder roads to link resettlement plots. Furthermore, the GMB is contributing to the transport problem in the area. In principle, GMB has the responsibility to send trucks to collect grain directly from the farmers but the GMB's only truck is overwhelmed by demand, since it services the whole district (Sibanda, 2010). Poor 
road network in the resettlement farms has led to delays in transferring produce to market centres thereby resulting in losses in farm produce. This is also a major barrier to smallholder farmers' participation in the production and marketing of high value horticulture commodities (Chisvo, 2000). Lack of reliable transportation of produce will also affect production. Once the agricultural produce fails to reach the market whilst fresh or in good condition, farmers will stand to lose. Thus, transport problems are also forcing smallholder farmers to sell their produce at a low price to middlemen who have access to transport and are in a good position to drive a hard bargain (Hungwe, 2008:1).

Farmers have resorted to use of draught power to cater for their transport needs (Gocha et al, 2007:94). These farmers ferry produce to the market using either donkey-pulled or ox-drawn carts. The means of transport is advantageous in that it is cheap, readily available and can scale down steep terrain. It may not need a prescribed route also. However, this kind of transport has several disadvantages. Among others, it carries limited amounts of grains, it is slow, and uncertain. It requires constant rest if distance is long and may depend on human muscle (Gocha et al, 2007:94). Motor vehicles which are faster, versatile and can carry produce in bulk are very expensive and many of these smallholder black farmers cannot afford hiring.

\subsection{Shortage of Labour Force}

By and large, the availability of labour is determined by the amount of capital that a farmer has at disposal and prepared to give as wages. Several black farmers in Congela lack capital to hire labour. Owing to shortage of capital, the majority of farmers depend on family members as a source of labour. Based on statistics, we observed that the new black farmers depended on family labour $(48 \%)$, village cooperative labour $(35 \%)$ and hired labour $(17 \%)$. We also observed that this labour is usually provided by elderly people and school children who usually avail themselves for work during weekends and school holidays. A small percentage of farmers make use of hired labour, whether casual or permanent. Casual labourers are hired during peak times, that is, during planting, weeding and harvesting periods. While some privileged farmers pay wages, the majority of them pay in material things such as grain, soaps or clothes. This kind of labour is unreliable because after completing the piece-work, the workers migrate to the next farm, hoping to get better conditions and higher wages.

Another category of labour is village cooperative labour. Farmers usually get organised into small groups and collectively offer their labour to service members of the group. This is a contingent measure which has been put in place to avert labour shortages. Whereas the system promotes social solidarity, it only benefits those people who can freely participate in group activities (Gocha et al, 2007: 95). 
Elderly farmers are side-lined as they cannot actively participate in those social group activities. Thus, shortage of labour remains one of the big challenges that undermine the ability of the new farming communities to increase productivity. This is how black farms are under-utilised (Pswarayi, cited by Chisvo, 2002:18). The under-utilisation of land in turn determines the proceeds from a given piece of land. Because they are not realising significant incomes, the farmers have generally remained poorer. According to Odreive (2002:54), labour is a form of production. He defines it as human effort or other work done by human beings and that this labour can be more productive through training. Family labour is very important for small holder production. It is cheap and readily available. Village work cooperative is whereby people outside the family come to exchange their labour not for money but with the hope for reciprocity at a later date. Crop production in small farming is also affected by labour to land ratios. Small scale farmers make the mistake of trying to grow too many hectares of land yet they do not have sufficient labour and resources. Farmers would have been better off growing fewer hectares of land at higher standard management. The labour force available at Congela is largely that of older people and younger children, all because of the general drift of younger people to towns. Family labour is advantageous in that it inculcates a sense of ownership and responsibility among the members themselves. It also suits the conditions and demands of small scale farming. However, family labour has its practical limitations given the fact that children avail themselves for work usually when they are away from school. Farm owners on the other hand rely on hired labour. This can be casual, permanent or both. The majority of farmers prefer casual labour that is hired during peak times of the cropping season: during planting, weeding and harvesting (Nhandara, 2003:28). Though hired labour is practically more efficient and effective than other forms of labour, it is expensive. This partly explains the failure by resettled farmers to make use of hired labour. In spite of the availability of the former farm tenants in the neighbourhood, the new farmers have not employed many of these (Utete, 2003:80). Village cooperative work involves labour that is shared communally in order to hasten work at critical times of production, for example at ploughing, weeding and harvesting (Gocha et al, 2007:95). However, community labour is not reliable since it is dependent upon one's continued participation in group activities.

\subsection{Erratic Availability of Inputs}

The government of Zimbabwe has been supporting the land reform programme by providing inputs to resettled black farmers as shown in the table below. 
Table 2: Government's Provision of Inputs to black farmers in Congela

\begin{tabular}{|l|l|l|l|}
\hline Year & \multicolumn{3}{|c|}{ Types of Inputs provided per individual farmer } \\
\hline & Seeds in kgs & Fertiliser in kgs & $\begin{array}{l}\text { Tractor tillage } \\
\text { power use in \% }\end{array}$ \\
\hline 2009 & 10 & $1 \times 50$ & 0.2 \\
\hline 2010 & 20 & $1 \times 50$ & 3.5 \\
\hline 2011 & 10 & $1 \times 50$ & 5.1 \\
\hline
\end{tabular}

Source: Interview with Nyaungwe, Congela Resettlement, 2010

Although the new farmers were provided with the inputs such as seed, fertilisers and tractor tillage power have been extended to farmers; the process was fraught with technical problems. For example, the tendency to wait for government assistance created a serious dependency syndrome among the farmers. One observer remarked that, 'We need farmers with skills, zeal and passion for farming instead of these perennial beggars of inputs or support' (Moyo, 2010:9). Many farmers hardly take any initiative to prepare their own land and procure seeds and fertilisers by themselves. The input support scheme is neither dependable. For example, seeds and fertilisers are not given timeously. Some farmers are therefore forced to make do without the hybrid seeds and fertilisers. A typical analogy was during the 2011/2012 planting season in which seeds were received in January, well after the planting season which starts in November was over (Nyaungwe, 2010). Farmers ended up selling seeds and fertilizers at the black market because they could no longer serve any purpose. This is how the farmers misused or abused inputs received from government.

The other problem concerning the government's input is that the inputs given to farmers are not adequate in terms of quantities and also in some occasions, not all basic inputs are provided. For instance, the District Development Fund (DDF) avails tractor tillage power to farmers upon payment of money (Shamu, 2010). In 2008, over 2500 tractors, 2500 cultivators and about 100 combine harvesters were distributed to selected farmers nationwide But, these tractors were not accessed so easily by farmers due to lack of money to buy diesel. The result is that poor farmers shun this tractor tillage power. The farmers end up resorting to draught power. For instance, some 750 animal drawn planters were allocated to black farmers despite the fact that these are regrettably ineffective (Mabasa, 2008:67). The consequence is that black farmers remain trapped in the vicious cycle of poverty. What must be noted is that the government has limited capacity to meet the needs of all resettled farmers. It is a mammoth task for the government to give satisfactory support to all beneficiaries of the land reform programme. Though determined to support them, the government got handicapped by the scarcity of capital. Farmers could not access loans from banks because they have no title deeds for the land (Masau, 2012:6). Although some banks like, Agribank, have been set up to offer agro-loans to farmers, the credit 
facilities are more difficult to handle for individual small scale farmers whose numbers are large. These credit facilities are usually limited to cooperative groups or large scale commercial farmers. Due to failure to get satisfactory support from government, some resettled farmers pointed out that their fortunes as landowners do not translate into tangible benefits as land continue to lie idle every year. This fact was echoed by one black farmer who remarked that 'I was among the beneficiaries of land reform but 1 do not have tillage power to fully utilise my land' (Masau, 2012:6). What must also be underscored is that government's effort to extend aid to farmers is on the hand, undermined by corrupt government officials and traditional chiefs who either horde or sell the inputs that are earmarked for resettlements.

\subsection{Lack of Farm Supervision}

The question of farm supervision is critical in any agricultural programme (Kujeke, 2001:30). AREX officers use several methods of supervision, like group lectures or individual discussions with farmers. Nevertheless, not all the farmers are able to attend these sessions, particularly elderly farmers. AREX officers also employ individual farm supervisions. In spite of its effectiveness, the method is rarely undertaken because it is a mammoth task for one resident AREX officer who is expected to supervise about 100 farmers in the Congela. Farmers normally convene at the homestead of a successful individual farmer and demonstrations are carried out using practical examples.

The majority of farmers are yet to be equipped with modern farming knowledge and skills. Until the government deploys a reasonable number of AREX officers, the farmers will continue to rely on traditional methods of farming. Commercial agriculture needs a sound knowledge and good management. This involves systematic planning organisation and implementation. Knowledge and farm management techniques in small scale farming are disseminated by the AREX officers who provide advice on how to improve farming methods. AREX officers advise the farmers with information on new seed varieties, fertiliser application and pest and disease control methods. Government should ensure that there is an AREX officer at every ward. However, there is woeful shortage of extension officers in resettlement schemes across the country. For example, the current ratio of extension officers to farmers is about 1:300 in the resettlement schemes.

In general, lack of research in small scale farming inhibits the achievement of optimum returns in agriculture. Peasant farmers, who are the beneficiaries of the land reform programme are inadequately educated, they cannot adapt easily to modern ideas and technologies on agricultural mechanisation. AREX officers employ many approaches in disseminating information to small holder farmers. Their approach emphasise on farmer-focused and farmer participatory systems of designing and implementing extension programmes. The major one is the target 
group approach in which specific target groups such as women headed households, landless farmers or farmers experiencing a particular problem like accessing credit or marketing are identified. The major advantage of this approach is that it focuses on a group of farmers usually to address a specific issue or concern. This method also allows for limited resources to be channelled to an identified needy group with defined objective. However, the disadvantage of the method is that difficulties are encountered in targeting the needy and focusing on a particular individual or group. The group or individual farmer may preclude support and services for other deserving clientele.

Other approaches or extension activities such as field days, demonstration trials and farmer competitions are also employed. These also help to provide technical advice to farmers. Theoretically, field extension agents are tasked with providing technical knowledge and information to farmers through regular and frequent contacts. They are supposed to relay the farmers' needs and concerns up the extension organisation's hierarchy to the policy and decision makers. However, the field extension workers tend to have limited contact with framers mainly due to the relatively high number of framers they are supposed to serve. The problem is compounded by lack of efficient communication and transportation facilities for both field level staff and the extension personnel. In addition, salaries and allowances of extension personnel are low, contributing to low morale and respect for the profession. In this regard, government has to work towards upgrading the standards of field agricultural extension skills to improve black production in the former white commercial farms.

\section{Concluding Remarks}

The land reform programme continues to generate shockwaves inside Zimbabwe and even beyond. It continues to be an emotive movement in the political discourses of Zimbabwe today. Its future is indeterminate as narratives of land grabbing across the country continue unabatedly. The government is failing to meets the demands of black farmers in terms of the provision for farming inputs and logistical support. Many resettled farmers tend to abuse government assistance. Many of them sell inputs at the black market and channel that money to other activities outside the core business of farming. Other notable challenges include marketing constraints, poor transportation, shortage of labour, lack of inputs and inadequate farm supervisions render the land reform programme a cosmetic arrangement as most farmers are disillusioned. Put differently, the land reform programme is failing to sustain humanity. If the GMB was offering prices for grain and processing payments expeditiously, the farmers could have been motivated into taking farming seriously. Because of non-promising market 
environment, some farmers are not utilising their land to the optimum capacity. Unavailability of transport greatly affects acquisition of inputs and also ferrying of produce to the market. Despite being just $25 \mathrm{~km}$ away from Kwekwe town, the farmers in Congela are doomed due to absence of a major road and bridges to link them to town. These farmers are secluded from markets and other sources of inputs which make farming a risky adventure. Black farmers have resorted to use of ox-drawn or donkey-pulled scotch carts to ferry agricultural produce to the market. Nevertheless, these modes of transport have a limited carrying capacity. Even farmers who are better placed financially cannot help the transport situation because the area is inaccessible. This explains why most farmers prefer the open market which reduces the transport challenges.

It is also apparent to note that the quality of labour also determines yields per hectare. If labour is drawn from the old and young children, the capacity to produce high yields is compromised. Some village cooperatives that are done under the auspices of human solidarity are providing prospects for hope of economic empowerment to the black farmers Cooperatives encourage social interaction which see some farmers end up even sharing farming implements. The success of one farmer inspires the other. However, it is disadvantageous in that it does not improve the economic status of farmers. Hired labour is expensive to sustain. A farmer may hire one or two workers on permanent basis, the rest may be casual labourers who are hired during peak periods like during planting and harvesting times. However, black labourers are usually migratory in search of better working conditions from one farm to the next. This migratory tendency is patterned by the fact that labourers are usually paid in kind and not in cash. Due to labour constraints in the area, land is not being fully utilised, farmers are cultivating land that is big enough for the available labour and this results in land degradation. While farmers are now generally aware of the need to use fertilisers and hybrid seeds, their inability to acquire them is a stumbling block. As a result, most farmers in Congela resettlement scheme are largely depended on the government aid in terms of inputs. Yet this aid has proved to be problematic and undependable as it is either distributed in trickles or comes late or may never come at all. Thus, the land reform programme is associated with technical contradictions. The majority of the farmers cannot afford acquiring inputs and implements and this render them economically handicapped. The AGRITEX Department helps farmers with information on new seed varieties, fertiliser application and improved farming methods. Group supervision of farmers and demonstrations by AREX officers are not very effective because they tend to dwell on generalisations. Some farmers have peculiar problems that demand individual attention and supervision hence lack of this service affects farm production. For instance, Congela area is services by one AREX officer. The issue is compounded by the fact that the officer does not have a means of transport to 
move from one village to the other hence a generally low performance in agriculture. We can conclude this work by suggesting two recommendations, thus:

- Resettled farmers are encouraged to form viable cooperatives in order to offset perennial labour blues. This new ethic of labour is, however, not a march going backwards to the days of socialist labour organisation.

- The government should be more committed on three critical areas: establishing more marketing depots, providing credit facilities through the banks, supplying enough inputs timeously and ensuring that more Extension Agricultural Officers are available to farmers regularly.

\section{References}

Chisvo, M. (2000). 'Reaping the Whirlwind Economic Liberalisation and Food Security', in Zimbabwe Catholic Institute for International Relations (CIIR), United Kingdom

Gocha, N. T, et al. (2007). Dynamics of Human and Economic Geography, College Press, Harare.

Goh Cheng, L and Morgan, G. C. (2000). Human and Economic Geography, New York: Oxford University Press.

Gwenzi, L. (2010). War veteran, Dunlop Extension, Kwekwe.

Halevi, I. (1987) A History of the Jews: Ancient and Modern, London: Bath Press.

Hungwe, S. D. (2008). 'The African Smallholder Farmer's Perspective, Zimbabwe Farmers' Union', in www.agritrade.org/publications/40\%20Book/PDFs/hungwe.pdf

Kujeke, R. (2001). Principles of Agricultural Extension, Harare: Jongwe Publishing Co.

Mabasa, S. (2008). 'Zimbabwe Agricultural Mechanisation Programme', in NewAfrican Magazine, Winter, London: IC Publication.

Magaloni, B., Weingasi, B. and Diaz, C. (2005). Why Authoritarian Regimes Sabotage Economic Growth, Land Reform in Mexico, London: Longman.

Masau, P (2012),. 'Resettled Farmers Fail to Utilise Land', in Newsday, January 18.

Max-Neef, M, (1991). Human Scale Development Conception: Application and Further Reflections, London: Apex Press.

Mnkandla, V.A. (2001). Environmental Systems, Bulawayo: College Desktop Publications.

Moyo, S, (2010). 'New Farmers have Failed Zimbabwe', in Newsday, January 17

Munowenyu, E. M. and Pritchard, J.M, (2005). Human and Economic Geography, Harare:, Longman.

Mutwira, L. et al, (2001). People Making History, Harare: Zimbabwe Publishing House.

Nhandara, E. et al, (2003). Geograpby Today-Human and Economic, Harare: Zimbabwe Educational Books.

Nyaungwe, B. (2010). New farmer, Congela, Kwekwe, 20 March.

Oldreive, B. (2002). Conservation Farming for Small-scale Resettlement and Cooperative Farmers in Zimbabwe, Harare; Rio Tinto Foundation.

Shamu, P. (2010). New farmer, Congela, 17 November. 
Sibanda, F. (2010). New farmer, Muwandi farm, Kwekwe, 29 March.

Rwodzi, M. (2010). New Farmer, Congela, Kwekwe, 17 November.

Tshuma, L. (2003). A Matter of (In) Justice: Law, State and Agrarian Question in Zimbabwe, Harare: Sapes.

Utete, C. (2003). Presidential Report on Land Reform Programme, Harare: Government Printer. 